\title{
Religious Education in Finland
}

\author{
TUULA SAKARANAHO \\ University of Helsinki
}

\begin{abstract}
In recent decades, the Finnish state has developed multicultural policies that aim at fostering the cultural identity of people coming to Finland from different ethnic and linguistic backgrounds. This aim has had clear practical consequences in the Finnish state-supported schools, where, along with the Finnish and Swedish languages, pupils with different linguistic backgrounds now have the right to learn their native tongue within the frame of the school curriculum. In similar fashion, the state favours a multiple solution as regards religious education, so that pupils belonging to different religious communities have the right to "education in accordance with their own religion". In addition, Ethics is taught to those pupils who are not members of any religious community. Consequently, several religions are today taught in Finnish schools, as well as secular Ethics. Nevertheless, the current system of religious education in Finland is ridden with contradictions. This article first offers an overview of the most recent developments, legal provisions and contents of religious education in state-supported schools in Finland. Next, it identifies some of the sore issues in the current system, and, finally, it reflects on the possible role of the Study of Religions in the field of religious education.
\end{abstract}

Keywords: Finland, religious education, state-supported schools, multiculturalism, Study of Religions

Religious education is an illuminating example of how complicated the issues involved in the negotiations of different interests are with regard to education (see Himanen 2012). In recent decades, religious education has gained new significance, both on the national and the European level. One can identify at least two reasons for the increased interest in religious education shown by national governments and European bodies, such as the Council of Europe or the European Court of Human Rights. First, a rapid increase of immigration to Europe after the Second World War set into motion a process of cultural pluralization, forcing European states to develop new multicultural policies in order to meet the challenge of growing diversity within European borders. Second, and partly linked with the first issue, both national and European bodies are increasingly concerned with maintaining the stability of the Eu- 
ropean social and political order against security threats coming both from inside and outside its borders. In particular, one can observe a clear change in European governments' policies from benign neglect to active management of new religious minorities, of which Muslims are often seen as the most challenging for the social and political order of a multicultural European society. (Turner 2011, 192-3; Laurence 2012.)

In Finland, the Ministry of the Interior published in 2008 a security programme where one of the goals was stated as the enhancement of good ethnic relations. In order to reach this goal, it was argued that both the majority and the ethnic minorities should know about different cultures and religions. Moreover, familiarity with one's own culture and religion would support the constitution and governance of one's identity. The document acknowledged, however, that there were serious shortcomings in the standard regarding teaching and teachers of religious education of the minority religions. Consequently, it aimed at making a survey on the education of minority religions and seeking solutions to the above-mentioned problems. (Sisäasiainministeriö 2008, 26-30; Sakaranaho, forthcoming.)

On a more practical level, schools act as some sort of barometers of social change, and mirror the growing cultural and religious pluralism of a society (cf. Davie 2000, 89). They have become important scenes for cultural encounters, and a real testing ground for the multicultural policies of a country. This is where the integration into the mainstream society of children and young people with different cultural backgrounds is measured in practice (see Alitolppa-Niitamo 2004, 81). At the same time, the formal education of state-supported schools reproduces the main cultural values of the society, and reinforces a given national identity. Education, thereby, is crucial when modern societies aim at confirming and redefining their unity and identity in the face of rapid global and local changes. (See Maréchal 2003, 22.)

When looking into the governance of religious education in Finland, at least three matters are closely intertwined. These are: first, the legal recognition of religious communities as a part of a particular church-state system and the subsequent institutionalization of their right to have religious education in state-supported schools; second, the status of religion as a subject matter in school; and third, the authority setting the aims of religious education and carrying the responsibility for its implementation. (See Sakaranaho 2006, 331; Kallioniemi 2007.)

Finland's church-state system is somewhat of an exception amongst European countries, since it recognizes two national churches, namely the 
Evangelical Lutheran Church of Finland and the Orthodox Church of Finland. ${ }^{1}$ The reason for this dual national church system lies in Finnish history, and it has had its impact also on religious education in state-supported schools. In Finland, members of registered religious communities have, subject to certain conditions, the right to 'education in accordance with their own religion' (Basic Education Act 1998), and therefore religious education in Finnish schools is 'separative', to use the terminology of Wanda Alberts (2007).

In the following, I will first take a brief look at the history of religious education in Finland and then move on to the contemporary Finnish legislation that lays down the main principles for religious freedom in general and for religious education in particular. Second, I will outline the main aims of the religious education curriculum as laid down by the National Board of Education. ${ }^{2}$ Third, I will take a brief look at the teacher education provision for different religions, and, finally, will introduce some of the recent critical discussion around religious education in Finland. ${ }^{3}$ My presentation will focus on the peruskoulu (the integrated institution providing the compulsory education phase from first to ninth grade) and the lukio (the academicallyoriented upper-secondary school) ${ }_{1}^{4}$ which between them constitute the main forum for religious education in Finnish state-supported schools (see National Core Curriculum for Basic Education 2004). ${ }^{5}$

\section{Development of Religious Education in Finland}

The history of Finland, located on the divide between Eastern and Western Christianity, has moulded the relations between church and state, ${ }^{6}$ which in turn has had an impact on religious education in school. The spread of

1 Henceforth, I will simply refer to the Lutheran Church and the Orthodox Church.

2 The Finnish National Board of Education is a national development agency, subordinated to the Ministry of Education and Culture. It is responsible for the development of pre-primary, basic (integrated primary and lower-secondary), general upper secondary, vocational upper secondary and adult education. See oph.fi.

3 I wish to thank Tim Jensen and Wanda Alberts for their invaluable comments on different drafts of my text. I also wish to extend my thanks to an anonymous referee for opening my eyes to yet another contradiction in the Finnish system of religious education.

4 The term Basic Education in Finland (peruskoulu) refers to nine years of compulsory comprehensive education. After that a student can choose between general upper-secondary school (i.e. high school) or vocational upper-secondary school, both lasting three years.

5 The English translation of the document is provided by the National Board of Education. See oph.fi.

6 For a more detailed account of the history of Finland, see Singleton 1998. For the church history of Finland, see Heininen \& Heikkilä 2002. For a brief summary of the history of religious freedom in Finland, see Sakaranaho 2006, 123-8. 
Catholicism to Finland was facilitated by the fact that Finland was part of Sweden for over six hundred years, from the thirteenth century until 1809. At the same time, Orthodox Novgorod was also seeking a foothold in Finland. The strife between these two contestants was settled in 1323, when a border dividing the East and the West was drawn from the Gulf of Bothnia to Karelia near Lake Ladoga. This border lasted for some two hundred years, during which time Sweden-Finland saw the gradual establishment of the Roman Catholic Church, with the foundation of church administration, church buildings and schools.

However, the sixteenth century saw a drastic religious and political upheaval in Sweden and Finland, brought about by the Reformation and the gradual development of the nation state. The Reformation in Finland marked the beginning of a period of 'collective and compulsory Lutheranism', when Finland was a country of 'strict religious uniformity, based on the ideal of a confessional state' (Seppo 1998, 849). In 1809, the Swedish era ended and Finland was annexed to Russia as an autonomous Grand Duchy. This change, however, did not lead to any major changes in the relations between church and state. The system of a state-run church continued, and religious freedom remained limited. With respect to religious minorities, the number of adherents to Orthodoxy grew considerably, and their position was strengthened with enlarged rights granted by the Tsar. (See Seppo 1998, 851-2; Heininen \& Heikkilä 2002, 141-8, 168-70.)

From the eighteenth century, Pietism and the Enlightenment started gradually to erode the consensus of collective and compulsory religion. Moreover, the ideology of liberalism spread from Continental Europe to Finland, whereupon the pressure to recognise religious freedom started to grow. As a result, a new canon law was passed in 1869, increasing the autonomy of the Lutheran Church, and allowing people to resign from the church in order to join another Christian denomination. (Seppo 1998, 852.) The number of Orthodox and Roman Catholic Christians, Jews and Muslims, however, remained very small, and the dominance of the Lutheran Church remained intact.

An important change concerning school education, however, came about with a statute enacted in 1865 in the countryside and in 1873 in the cities. This statute established local government based on direct participation. From then on, ecclesiastical and secular administration were separated from one another, and the municipalities took over such 'secular' tasks as healthcare and education. (Finnish Local Government 1981.) Although municipalities were now in charge of primary school education, one of its main aims was to bring 
up children as 'true Christians', and the Church continued to take care of the religious education in school (Seine 2000, 29-30; Jamisto 2007a, 31; Sakaranaho \& Salmenkivi 2009, 453). The only minority at this time with its own religious education were the Orthodox (Seine 2000, 36-9; Aikonen 2007, 42-3).

Towards the end of the nineteenth century, changes occurred in the religious field when the number of Christian groups, originating both in Finland and abroad, grew considerably. In 1889, a law was passed which allowed Protestant minorities to organise. (Seppo 1998, 853.) This law also made it possible for the members of Christian minorities to opt out from the Lutheran religious education in school if their churches could offer their own religious education instead (Seine 2000,38). The only non-Christian minorities in Finland at that time were the Jews and Muslim Tatars. The Jews gained the right to establish their own school already at the end of 1892 , but the school had to be closed down later, due to financial problems (Weintraub 2007). The Tatars, on the other hand, started to arrive to Finland from Russia as wandering pedlars during the latter half of the $19^{\text {th }}$ century, and it took some decades before they were well enough established in the country so as to have children attending Finnish schools (see Leitzinger 2006).

In the aftermath of the Russian Revolution, Finland gained its independence in December 1917. The 1919 Constitution guaranteed all Finnish citizens the right to practice their religion in public and private. It also declared the Finnish state neutral with respect to religion. The civil rights and duties laid down by the state thus no longer depended on religious affiliation. Nevertheless, due to central role of the Lutheran Church in Finnish history and its membership embracing the vast majority of Finns, it was accorded a privileged position as a national church. In addition, the Constitution also recognised the special legal status of the Orthodox Church as the second national church of Finland. (Heininen \& Heikkilä 2002, 199-202; Seppo 2003, 44.) The Finnish state thus recognised not one but two distinct national churches, a fact also reflected in the provisions concerning religious education in school.

The constitutional right to freedom of religion was implemented by the Freedom of Religion Act of 1922 (267/1922). In addition to the right to practice religion in public and private, the law also granted, for the first time in Finland, the right not to belong to any religious community. This right was also acknowledged with respect to religious education in Finnish schools. The Act stated that if a primary school, whether run by the state or a municipality, offered religious education according to the confession of a certain religious community, a pupil who belonged to some other religious 
community, or to none, should be exempted from such religious education if his or her parents so wished. In the aftermath of Finnish independence, the Jews gained full civil rights, and in 1918 re-started a Jewish school in Helsinki, a school still functioning (Weintraub 2007). ${ }^{7}$

In 1923, the Primary School Act set the foundation for religious education in schools, specifying that the school curriculum should include, in addition to other subjects, religious education and education of ethics. Religious education was to be taught, first, according to the confession of the majority. Second, schools should offer religious education according to some other confession if there were twenty pupils belonging to a particular religious community and if their parents so requested. This provision was particularly important for the Orthodox. The law also stated that pupils who did not belong to any religious community should be offered an education in (secular) ethics. (Laki kansakoulun järjestysmuodon perusteista 137/1923.)

In sum, already by the 1920s the Finnish state acknowledged the right of pupils in state-supported schools to religious education, both for the religious majority and for minorities, alongside education in (secular) ethics. From the start, it thus promoted a system of 'separative religious education' (Alberts 2007). These same principles are, with some modifications, still in force in Finland today.

\section{The Current Legal Framework}

Finland is a welfare state, promoting the equality of its members before the law. This principle of equality is also a guiding principle in relation to religious rights and their implementation in Finnish society (see Perustuslaki ${ }^{8}$ 1999; Uskonnonvapauslaki ${ }^{9}$ 2003).

The Constitution of Finland states that 'Everyone is equal before the law' (2:3) and that '[d]emocracy entails the right of the individual to participate in and influence the development of society and his or her living conditions' (1:2). Moreover, it says that '[n]o one shall, without an acceptable reason, be treated differently from other persons on the ground of sex, age, origin, language, religion, conviction, opinion, health, disability or other reason

7 The Tatars ran their own school in Helsinki from 1948 to 1969, and the Adventists were the first Christian denomination to open a Christian school in 1932 (see Sakaranaho \& Salmenkivi 2009, 454).

8 For an 'unofficial' translation in English, see The Constitution of Finland 1999. Henceforth, I will refer to this English language source of the Finnish Constitution.

9 In English: Freedom of Religion Act (2003); see Sakaranaho 2006, 135-62. 
that concerns his or her person' (2:6). These fundamental rights of the Constitution are also reflected in the Act on the Integration of Immigrants and Reception of Asylum Seekers (1999), which defines integration as 'the personal development of immigrants, aimed at their participation in working life and society while preserving their own language and culture'. ${ }^{10}$ The Finnish government thus acknowledges the right of members of the population belonging to different ethnic groups to maintain and develop their own language and culture. This provision has clear practical consequences for Finnish schools, and in the metropolitan area of Helsinki in particular, where several languages are taught as a part of the school curriculum. ${ }^{11}$

In addition to language teaching, religious education is another important area where the right of immigrants to preserve their culture is taken into consideration. The Basic Education Act (Perusopetuslaki 454 / 2003: $13 \S)^{12}$ and the Upper-secondary Education Act (Lukiolaki 455 / 2003: 9 §) grant the right of children belonging to registered religious communities ${ }^{13}$ to receive, subject to certain conditions, 'education in accordance with their own religion' (oman uskonnon opetus) as a part of the school curriculum.

In more detail, the Basic Education Act (13:1) states, first, that ' $[t]$ he provider of basic education shall provide religious education in accordance with the religion of the majority of pupils. In this case, religious education is arranged in conformity with the religious community to which the majority of pupils belong.' In addition, pupils who are not members of the majority can also attend this particular religious education if their parents / carers so wish. (Basic Education Act 1998, 13: 1). Since around 80 per cent of the Finnish people are members of the Lutheran Church, it is Lutheran Religious Education which in practice is predominant in Finnish schools. ${ }^{14}$

10 See Section Chapter 1, Section 2: Definitions (362/ 2005).

11 For the recommendations by the National Board of Education on teaching different languages in school, see the National Core Curriculum for Basic Education 2004.

12 See the Basic Education Act 1998, Section 13: Religious education and ethics (Amendment 454/2003). The English translation of the Act is provided by the Finlex Data Bank.

See finlex.fi/en/.

13 A minimum quota of 20 people is needed in order to start a registered religious community (uskonnollinen yhdyskunta). See Chapter 2 of the Freedom of Religion Act (Uskonnonvapauslaki 2003); see also Sakaranaho 2006, $143 \mathrm{ff}$.

14 It is estimated that of the pupils taking part in basic education, 93 per cent participate in Lutheran RE, 1,3 per cent in Orthodox RE, 2,9 per cent in Ethics and 1,2 per cent in Muslim education (Iivonen 2010). The equivalent numbers in Helsinki somewhat differ from those of the whole country, as follows: 78 per cent Lutheran, 3 per cent Orthodox, 11 per cent Ethics, and 5 percent Islam (see Sakaranaho \& Salmenkivi 2009, 458). The numbers of Orthodox pupils are highest in the Eastern provinces of Finland. Should they locally outnumber the Lutheran pupils, the Orthodox religion would naturally be the 'religion of the majority' in the meaning of the law. 
Second, the municipalities are obliged to organise religious education for pupils or students belonging to the Lutheran Church or to the Orthodox Church if they number three or more and do not attend the religious education of the majority (Basic Education Act 1998, 13: 2). Due to the clear majority of Lutheran pupils, this provision, in practice, primarily concerns the Orthodox pupils and students. Third, for members of registered religious communities other than those of the Lutheran or Orthodox faiths, municipalities are obliged to organise religious education if there are three or more pupils or students in the area of the municipality belonging to a particular registered religious community, and if the parents of these pupils, in the case of the peruskoulu, or students themselves in the case of the upper-secondary school, so request (Basic Education Act 1998, 13: 3). Thus, in contrast to the compulsory Lutheran religious education, the education of the minority religions, other than that of the Orthodox, is distinctively voluntary and, at least in principle, left to the activity of the parents or students themselves.

Fourth, in addition to religious education, municipalities are also obliged to organise Ethics education ${ }^{15}$ (elämänkatsomustieto) for those pupils who are not members of any religious community, and who do not participate in the religious education of the majority (Basic Education Act 1998, 13: 5). The minimum number of pupils is three, but the request of parents is required only in cases where a pupil is a member of a religious community and where the municipality does not organise education in her or his religion. Thus, education in Ethics is more or less on the same standing with education in Orthodox religion, where the number of three pupils is needed but where no request from the parents or students is necessary.

In addition, the Basic Education Act $(1998,13: 6)$ also states that ' $[a]$ pupil who does not belong to any religious community may, at the request of his or her parent/carer, also participate in religious education [...] which, in view of his or her upbringing and cultural background, evidently corresponds to his or her religious beliefs'. This provision is important from the point of view of individuals of religious minorities who do not seek membership in a registered religious community. For instance, only some 10 to 15 per cent of Muslims are members of an Islamic community registered according to the Freedom of Religion Act. The above-mentioned provision allows pupils from Muslim families to take part in Islamic education if their parents so

15 Teachers of the subject use the English translation "Ethics and Philosophy of Life" (see www.feto.fi). Since the Basic Education Act and the National Board of Education use the term Ethics, I will follow their terminology (see Basic Education Act 1998, Section13; National Core Curriculum for Basic Education 2004, 213-9.) 
wish, provided that this education is already available. For pupils who do not attend any of the above-mentioned forms of religious or ethics education, the schools need to organise some other activity. (See Perusopetuslain muutoksen vaikutukset uskonnon ja elämänkatsomustiedon opetukseen sekä koulun toimintaan 2006.) Moreover, in cases where a pupil is a member of more than one registered religious community, it is the parents who decide what kind of religious education the pupil will attend (Basic Education Act 1998, 13: 4). In practice, the schools inquire about the attendance of new pupils in religious education by sending out a letter to parents, where they can express their wishes in this matter.

Pupils do not only have a right to education of a religion or Ethics. Religious education, in accordance with the Basic Education Act $(2003,11 \S)$, is a compulsory subject. Thus, depending on their membership (or nonmembership) in a religious community, a pupil should attend religious education of the majority, i.e. Lutheran religious education, or that of Orthodox religion, or Ethics. The same obligation does not, however, concern minority religions other than the Orthodox religion. Hence, Muslim or Buddhist pupils for instance have a right to attend religious education in accordance with their religion if such is available and provided that the parents express their wish for it, but they are not obliged to. (See Perusopetuslain muutoksen vaikutukset uskonnon ja elämänkatsomustiedon opetukseen sekä koulun toimintaan 2006.) The law thus treats members of different religions differently. By curtailing the freedom of choice of the Lutheran pupils, it effectively discriminates against the members of the majority religion. On the other hand, pupils whose family adhere to a religion but who are not members of any registered religious community have the widest range of choice; they can choose between Lutheran religious education, Ethics and, if it is available, religious education in accordance with their religious beliefs. The law thus effectively privileges adherents of minority religions. In practice, this mainly concerns Muslims, who constitute the largest number of minority pupils after the Orthodox (see Onniselkä 2011, 125).

Pupils can also apply for exemption from religious education in school, and instead take part in education given by their own religious community outside of school. Pupils using this opportunity most often belong to the Jehovah's Witnesses or the Mormons. (See Talli 2003.) Religious education outside the school curriculum is not, however, recognised by the municipalities, and therefore these pupils do not receive a grade for religious education in their school report. 
In the aftermath of the above-mentioned laws, the National Board of Education issued a briefing in order to clarify some issues that had caused confusion. When looking at the previous and current provisions concerning religious education, there was a change in the wording from 'education according to the pupil's confession' (oppilaan oman tunnustuksen mukainen opetus) to 'education in accordance with the pupil's own religion' (oppilaan oman uskonnon opetus). The change of vocabulary gave rise to questions as to how to understand the nature of education in accordance with the pupil's own religion; how does this differ from the previous regulation specifying education according to the pupil's confession, and how does education in accordance with the pupil's own religion relate to religious practice in class? The National Board of Education clarified that this change in vocabulary did not necessitate any changes in the actual contents and arrangements of religious education; what the new provision simply did was to explicate religious education in its current form. (Perusopetuslain muutoksen vaikutukset uskonnon ja elämänkatsomustiedon opetukseen sekä koulun toimintaan 2006. ${ }^{16}$ In the discussion about the nature of current religious education, it was said that the term 'confessional' gave the impression that religious education had a direct link with the teachings of the Church which, however, was not the case (see Pruuki 2009, 387).

For the current model of religious education to be maintained, however, it needed to be organized so as not to include practice of a religion, which was characteristic of confessional religious education (See livonen 2004; Sakaranaho \& Salmenkivi 2009, 458-9; see also Seppo 2003: 182-4). Religious education should be based on knowledge, rather than commitment, and on the pedagogical aims of the school rather than the interests of religious communities (cf. Hella \& Wright 2009). At the same time, the National Board of Education emphasized that one of the most important aims of religious education was to familiarize pupils with their own religious tradition. Thus, learning about prayers, hymns and religious service was an elemental part of religious education and, therefore, pupils could also visit a church or a mosque in order to get better acquainted with their religion (Perusopetuslain muutoksen vaikutukset uskonnon ja elämänkatsomustiedon opetukseen sekä koulun toimintaan 2006). This, however, was not religious practice in the meaning of Section 11 of the Constitution of Finland (1999). Since religious education was separated from religious practice, it also removed any (valid) reasons

16 Freely translated into English: 'The Implications of the changes in the Basic Education Act for Education in Religion and Ethics as well as other practices of schools.' See www.oph.fi. This document is not available in English. 
for applying for exemption from religious education on the grounds of the constitutional right not to participate in the practice of a religion against one's conscience.

\section{Religious Education Curricula}

In Finland, the National Board of Education issues a national curriculum ${ }^{17}$ for the school subjects in the peruskoulu and senior-secondary lukio. Drafting a new basic curriculum for religious education is a long process, involving representatives of the National Board of Education, municipalities, schools and religions. Usually the need for drafting a new curriculum arises in a municipality where the number of pupils belonging to some religious community starts to rise. The municipality then notifies the National Board of Education, which sets up a working group consisting of experts in education or in a particular religion, experienced school teachers and persons who are interested later on in teaching the religion in question, ${ }^{18}$ and, in some cases, representatives of the religious community whose religion is to be taught in school. ${ }^{19}$ A representative of the National Board of Education chairs the group. The starting point is the National Core Curriculum for Basic Education in general, and the general aims of religious education in particular. The basic curriculum for a religion needs to be clearly in line with the general aims of the school, rather than those of a religious community. The group makes several drafts, which are read by the various interested parties, and the final version is issued by the National Board of Education (Jamisto 2007b). ${ }^{20}$

The National Core Curriculum for Basic Education (Perusopetuksen opetussuunnitelman perusteet 2004$)^{21}$ outlines the general aims of religious education as follows:

17 The National Board of Education uses in its official documents the term 'curriculum' instead of 'syllabus' and the same will be done here.

18 Usually these people are immigrants or converts who are rather committed members of a religious community and / or seeking suitable employment. Their level of education varies a great deal.

19 There are no definite rules on the set up of a working group for drafting a curriculum of a minority religion (see Jamisto $2007 \mathrm{~b}$ ).

20 For a more detailed description of the process, see Jamisto's interview with Pekka Iivonen who is in charge of religious matters in the National Board of Education (Jamisto 2007b). In this interview, livonen said that, in the most recent process of drafting the basic curricula of all religions, the aim was to weaken the link between the school and religious communities whose religions where taught at school (Jamisto 2007b, 121).

21 The following revised National Core Curriculum for Basic education will be published by the National Board of Education in 2016. See http://www.oph.fi/ops2016. 
Instruction ${ }^{22}$ in religion emphasizes the pupil's own religious knowledge and readiness to encounter other religions and views, especially spiritual traditions that exert influence in Finnish society. The task of instruction of religion is to offer the pupils knowledge, skills, and experiences, from which they obtain materials for building an identity and world-view. (National Core Curriculum for Basic education 2004, 202.)

In addition to the overall goal of enhancing pupils' identity building, the objectives of religious education, in more detail, aim at familiarizing the pupil with his or her own religion and with the Finnish spiritual tradition (suomalainen katsomusperinne), introducing the pupil to other religions, helping the pupil to understand the cultural and human meaning of religions, and educating the pupil in ethical living while helping him or her to understand the ethical dimension of religion (National Core Curriculum for Basic education 2004, 202). Unfortunately, the National Board of Education does not explicate what exactly constitutes 'the Finnish spiritual tradition' to be taught. The text uses the plural when referring to different religions and worldviews prevalent in Finnish society, but refers to the Finnish spiritual tradition in the singular, as if it was some kind of unitary whole, well-known to all. (See Sakaranaho 2006, 343.)

In any case, religious education in Finland should, on the one hand, include information of one's own religious tradition, and, on the other hand, provide pupils and students with information about other religions and worldviews as well. In other words, the aim of religious education in school is a wide all-round education concerning different religions and outlooks on life. The justification for this sort of religious education is the necessity to bring up young people who, as members of a pluralist society, should be able to make independent value judgements, to take social responsibility, and to participate in cultural interaction. With respect to cultural interaction, pupils and students should have a good command of 'cultural reading skills' (kulttuurinen lukutaito) concerning religions, and understand the importance of religion for individuals, societies and cultures. (Seppo 2003, 180; cf. Sakaranaho 2006, 343; Hella \& Wright 2009.)

In addition to the above-mentioned general aims of religious education, the National Core Curriculum for Basic Education (2004) also lists the general aims of Lutheran and Orthodox religious education and of Ethics. The

22 'Instruction' is a translation here of the Finnish term 'opetus', i.e. 'teaching', which does not have any connotations relating to the nature of religious education as such. It does not refer to 'religious' religious education. 
overall aims concerning education for religions other than the Lutheran and Orthodox are listed in a separate document published by the National Board of Education (see Perusopetuksen muiden uskontojen opetussuunnitelmien perusteet 2006).

The core curriculum for both Lutheran and Orthodox religious education reiterates the general aims of religious education, namely to provide pupils with a wide all-round education concerning different religions and outlooks on life. However, they differ somewhat in their main points of departure. While the main focus of Lutheran religious education is 'to introduce the pupils in diverse ways to religious culture and bring out the main factors from the pupil's development and growth', the Orthodox religious education states as its main concern 'the strengthening and maintenance of the pupil's Orthodox identity' (National Core Curriculum for Basic education 2004, $202,207)$. It has been noted that contemporary Lutheran religious education represents some sort of general Christianity (yleiskristillisyys), rather than Lutheranism in any strict sense (Pyysiäinen 2000, 13, 15; Seppo 2003, 181). As against this, the focus in Orthodox religious education is clearly on developing the pupil's Orthodox identity, a difference that has been explained by the fact that identity construction is vital for the survival of a religious minority (Lyhykäinen 2009, 474-5).

For the first five grades, the main contents of Lutheran religious education focus on the Bible, ethical issues and Lutheran church life, as well as introducing 'common and divergent features of Judaism, Christianity and Islam'. Orthodox religious education, at this level, contains instruction in the church year and saints, in what it means to be a church member, in the Bible, in liturgical life and dogma and in ethical values. In similar fashion to Lutheran RE, it also deals with Judaism, Christianity and Islam. From the sixth to the ninth grade, both curricula aim at deepening pupils' understanding of their own religion and the religion of others, as well as supporting 'the formation of the pupil's own worldview and ethical points of view'. In addition, pupils should be familiarized with world religions. (National Core Curriculum for Basic Education 2004, 202-11.)

Interestingly, the curriculum for Lutheran religious education from the sixth to the ninth grades lists several matters to be taught as part of the Finnish 'spiritual tradition' mentioned above. First, the aim is to give 'a general picture of the Finnish religious situation, with emphasis on the Lutheran and Orthodox churches; other Christian churches and communities; other religions and non-religiousness'. It also deals with religious freedom, and with membership in the Lutheran Church, including Lutheran activities 
such as the tradition of singing hymns and other musical activities. Finally, it also looks at ancient Finnish folk beliefs, and at religion in Finland from the Catholic Middle Ages till the Reformation and its aftermath. (National Core Curriculum for Basic education 2004, 205.) In other words, in Lutheran religious education, the Finnish spiritual tradition is understood very much from the Lutheran point of view. Since the curricula for other religions do not list their aims with respect to the Finnish spiritual tradition, it is not possible to say how it is to be understood from their point of view.

The starting point of Ethics is multidisciplinary, including philosophy, social science, and cultural studies. Its goal is 'to give the pupils the material to grow into independent, tolerant, responsible, and judicious members of society', support their 'growth into full, democratic citizenship', in a globalizing and swiftly changing society. Ethics, moreover, is 'guided by the sense of the pupil's opportunities to grow into free, equal, and critical creator of a good life'. The first five grades of Ethics contain instruction in human relations and moral growth, self-knowledge and cultural identity, human rights, and issues concerning the environment and nature. From the sixth to the ninth grade, the aim of Ethics is to 'deepen the pupil's understanding of their own philosophies of life and conceptions of the world', and to provide fundamental information about a variety of worldviews and religions. The contents of Ethics at this stage focus on citizenship and a good society, different philosophies, culture, ethics and good life, and on the future for individuals, society and nature. The curriculum of Ethics deals with non-religiousness, but does not explicitly refer to teaching about world religions. (National Core Curriculum for Basic Education 2004, 213-8.) In practice, it, however, does also deal with different religions as well. ${ }^{23}$

In addition to Lutheran and Orthodox religious education and Ethics, the National Core Curriculum for Basic Education also makes reference to 'other religions'. It says that '[i]nstruction in other religions adheres to the principles of the national core curriculum for the religions presented above, particularly the objective drafted for all religious groups' (National Core Curriculum for Basic education 2004, 212). The 'other religions' include five Christian denominations, namely the Catholics, Adventists, the Free Church, Herran Kansa [The Lord's People] and Kristiyhteisö [The Christ Community]. It also provides a curriculum for the religion of the Latter Day Saints [Mormons], Judaism, Islam and Bahá'í, Buddhism and the religion

23 Personal communication with Eero Salmenkivi. See also Salmenkivi 2007. 
of the Krishna movement (ISKCON) ${ }^{24}$ (Perusopetuksen muiden uskontojen opetussuunnitelmien perusteet 2006). As a general observation, it can be noted that all of the above-mentioned curricula reiterate the need to strengthen the pupil's identity in accordance with a religion, while giving them information about other religions as well, the main emphasis being on religions prevalent in Finland.

What is noticeable about the different curricula for religious education, however, is that there are seven curricula dedicated to education in Christianity, but only one for the other 'world religions'. Thus, for instance, Muslims learn in school about 'General Islam', which is thus assumed to be suitable for both Sunni and Shia (see Perusopetuksen muiden uskontojen opetussuunnitelmien perusteet 2006, 24-7; Onniselkä 2011, 131-4; Sakaranaho, forthcoming). In a similar fashion, the education of Buddhism does not recognize its inner differences. In contrast to Islam and Buddhism, education for Hinduism in Finnish schools is provided by one particular branch of it, namely that of the Krishna movement, i.e. ISKCON (see Broo \& Kontala 2007). In sum, there are clear discrepancies as regards the curricula of different religions.

In addition to the basic national core curricula for the various kinds of religious education, the municipalities are obliged to draft their local curricula, in principle supposed to be in line with the national ones. ${ }^{25}$ In practice, this, however, is not always the case. For instance, some local curricula of Islam do not follow the Basic Curriculum of Islam, issued by the National Board of Education (Onniselkä 2011, 133-4).

\section{Teacher Education}

In order to be a qualified religious education teacher in state-supported schools in Finland, one needs to have a Master's Degree in a relevant subject at university level, a sufficient level of studies in teacher education, and a good command of the Finnish or Swedish language (see Asetus opetustoimen henkilöstön kelpoisuusvaatimuksista 1998). In order to qualify as a religious education teacher, moreover, a teacher needs a certain number of credits in the relevant religion, either included in the Master's Degree or taken as

24 The Krishna movement is the only Hindu religious community in Finland that has been active with respect to religious education. It is well organized and led by native Finns who are familiar with the Finnish legislation and school system.

25 For an overview of the National Core Curriculum of Islam and the curricula of Islam in metropolitan Helsinki, see Sakaranaho 2006, 356-74. 
additional studies. ${ }^{26}$ At present, it is not possible to have a Master's Degree with Ethics as a major subject, and therefore the studies for teaching Ethics are included in the student's minor studies (see Salmenkivi 2007, 88-92). Previously a religious education teacher had to be a member of the registered religious community whose religion she or he was teaching, but with the introduction of the recent Freedom of Religion Act in 2003, this provision was abolished (see Perusopetuslain muutoksen vaikutukset uskonnon ja elämänkatsomustiedon opetukseen sekä koulun toimintaan 2006). In consequence, a person can in principle teach any religion and all the religions as well as Ethics, provided that she or he has the relevant qualifications to do so.

The training for Lutheran religious education teachers is provided by four universities in Finland: the University of Helsinki, University of Turku, University of Eastern Finland, and Åbo Akademi University. The largest numbers of Lutheran religious education teachers are educated by the University of Helsinki, where a certain number of students of the Faculty of Theology can specialize as subject teachers. Since 2007, it has been also possible for students of the Study of Religions in the Faculty of Arts to specialize in teacher education for religion as part of their Master's Degree. ${ }^{27}$ This system was adopted by the University of Helsinki from the University of Turku, where the Study of Religions is taught in the Faculty of Humanities, but where students can study Lutheran theology in order to specialize within their Master's Degree as religious education teachers. The reason for adopting the Turku system at the University of Helsinki was to offer an opportunity to students of the Study of Religions in the Faculty of Arts to gain a teaching qualification in religion, similar to that option enjoyed by the students of the Faculty of Theology.

At the same time, the aim of this new teacher education program was - perhaps more importantly - to open an avenue for teacher education for minority religions. At first, this mainly concerned Islam, which had been taught in schools in metropolitan Helsinki since the 1980s, and where the

26 See the home page of the religious education teachers' union: http://www.suol.fi/index. php/uskonnonopetus-suomessa/uskonnon-aineenopettajankoulutus.

27 The Study of Religions department at the University of Helsinki has a chair in two faculties, namely the Faculty of Theology and the Faculty of Arts. It takes in yearly 11 students of the Faculty of Humanities. Students in the Faculty of Theology can freely choose the Study of Religions as their main subject and from 20 to 30 students make this choice each year. See http://www.helsinki.fi/teol/usktl/english/index.htm. 
need for qualified teachers was very acute (see Sakaranaho 2006, $352 \mathrm{ff}$ ). ${ }^{28}$ In addition to Islam, one can now also study to be a teacher of Buddhism. ${ }^{29}$ The teacher training for minority religions is divided between the Study of Religions and Teacher Education departments, the former providing students with studies in the subject matter related to the religion in question, and the latter taking care of the educational studies and teaching skills. The subject studies of Islam and Buddhism include 12 ECTS credits in the Study of Religions and 48 ECTS credits in Islam and Buddhism respectively. The last mentioned studies are divided into four modules, of which the first two are studied at BA level and the latter at the MA level. These modules concern, first, the history of Islam and Buddhism respectively; second, Islamic or Buddhist texts and concepts; third, the Islamic or Buddhist way of life and culture; and fourth, the law, dogma and ethics of the religion in question. (See Uskontotiede: Opinto-opas 2012-2013.)

The textbooks used in teacher education cover the religions' primary sources, and core literature produced by authors from the religions in question, but the main emphasis is on the scientific study of these religions. With respect to the scientific approach, the emphasis on 'Western Islamic studies' has recently been criticized by members of the Union of Teachers of Islam in Finland, registered in 2011, who, instead of the Study of Religions, would welcome the establishment of a Department of Islamic Theology as the main provider of teacher training of Islam in Finland (see Onniselkä 2011, 137). Departments such as this have recently been established in Germany, for instance, but there is nothing to suggest a similar development in Finland, not in the near future anyhow.

28 Starting teacher education for Islam was a long process, which began already at the end of the 1990s when a couple of teachers of Islam approached the Faculty of Theology at the University of Helsinki, inquiring about its willingness to establish such studies. In the beginning of 2000, the Faculty granted 30000 Finnish marks (approximately $€ 5000$ ) for a group, headed by myself, to start planning teacher education of Islam. In 2002, the National Board of Education funded a weekend course for teachers of minority languages and religions, and in connection with that course I had a chance to visit classes of Islam, Catholic and Orthodox religious education. The problem with this course was that it did not count towards a formal teaching qualification, which lead to the second phase where planning was started for teacher education for minority religions as part of a degree program at the University of Helsinki. The Ministry of Education funded a project, headed by myself and Eero Salmenkivi, to research and plan these studies. Finally, teacher education for Islam started in 2007, and it was followed by studies in Buddhism a couple of years later.

29 There were some negotiations to start teacher education for the Krishna movement at the University of Helsinki, but in the end they decided to take care of it within their own university, which has a branch in Helsinki. It is not clear yet how this separate schooling of teachers will work out. 
Åbo Akademi University caters for teacher education for Lutheran religious education in the Swedish language, whereas the University of Eastern Finland offers teacher training for students of both Lutheran and Orthodox religious education. In addition, some students of the Faculty of Theology at the University of Helsinki can also specialize as teachers of Orthodox and Catholic religious education as a part of their Master's Degree in (Western) Theology (see Jaanu-Schröder 2007, 81-2). In sum, there are several avenues for acquiring the qualifications as a teacher of Lutheran religious education, whereas the University of Eastern Finland is the main provider for teacher education of Orthodox religion (see Aikonen 2007), and, as was mentioned above, teachers of Islam and Buddhism are educated at the University of Helsinki. In addition to the religions mentioned above, one student has qualified for Jewish religious education and one for the Krishna movement at the Department of Teacher Education at the University of Helsinki.

\section{Issues of Discussion: How and for Whom?}

In Finland, the question as to what is the best way to organize religious education in state-supported schools is a constant topic of debate. However, there is no actual research available on these debates, and, therefore, it is not possible to give any systematic and detailed account of them. Instead, I will bring up some issues of discussion concerning the questions as to how and for whom religious education should be organized.

Religious education in Finland is, as said above with reference to Wanda Alberts 2007, 'separative'. Even though it seems that this model has a fairly wide support in Finnish society, there are also those who would welcome some sort of integrated religious education, often using the Swedish model with a general knowledge of religion (religionskunskap) as an example. The main justifications for adopting this 'Swedish model' are practical considerations. The implementation of the current 'denominational pattern' of religious education is becoming 'increasingly more difficult and expensive' (Holma 2000, 38, 41). The obvious outcome of the current system of religious education in Finnish schools is a growing plurality of religions taught in class. In recent decades, with the growing multiculturalism of Finnish society, the number of registered religious communities in Finland has rapidly increased. At the end of the 1980s, for example, there were only some five registered Islamic communities, but today their number is over 20. The increased plurality of religious communities also has an impact on 
schools, especially in metropolitan Helsinki, where religious education is provided for several different religions.

In addition to the increase in the number of different religions, the demand for differentiated religious education is also gradually increasing due to the internal heterogeneity within the religious communities. Drawn to its logical conclusion, the law in the present form could lead to a situation where religious education is not only given in different religious traditions, such as Islam and Buddhism, but also in different schools of these traditions, in similar fashion to Christianity. Whatever the case may, currently Christianity is taught according to different denominations but other religions are not. In other words, religions are treated equally before the law only in principle but not in practice.

The current system of religious education thus increases the cost and workload of municipalities, the main organizers of peruskoulu and lukio education. For small municipalities in particular, the demands arising from the growing plurality of religious education are already now overwhelming. For this reason, the Federation of Municipalities (Kuntaliitto) has argued for the 'Swedish model'. (See Liiten 2003.) One needs to keep in mind that religious education is not the only field where the growing cultural diversity in Finland adds to the workload of schools. As was mentioned above, immigrant pupils also have the right to study their own language, and, moreover, are taught Finnish as their second language; and the schools need to provide the time and resources to accommodate all these subjects. (Sakaranaho \& Salmela 2008, 462.)

In addition to these practical reasons, there are also those who support integrated religious education from an educational point of view, arguing that the separative or denominational model favours segregation of pupils in class, something which in turn does not allow much room for intercultural dialogue. In other words, teaching religions and religious education separately is not in line with the aim of religious education to bring up young people able to participate in cultural interaction and to have a command of 'cultural reading skills' (kulttuurinen lukutaito). (See Kallioniemi 2007.)

The increasing religious plurality of Finnish society notwithstanding, it is the organisation of Lutheran religious education which over the years has dominated the debate about religious education in Finland. As mentioned above, the Basic Education Act, in accordance with the Freedom of Religion Act, grants the right for religious education of the pupil first and foremost with respect to her or his membership of a religious community. In so doing, it reflects the general concept of religious affiliation in Finland, a concept 
that is based on registered membership of the Finnish Lutheran Church rather than on believing or behaving in a certain way. (See Niemelä 2003; Sakaranaho 2006, 32-3.)

When the most recent Freedom of Religion Act (2003) was being drafted, the obligation of the members of the Lutheran Church to attend Lutheran religious education in the basic schools was debated in a special issue of the Finnish Journal of Theology in 2001. In this issue, a prominent Finnish legal scholar of human rights, Martin Scheinin, drew attention to international agreements on human rights as well as to Finnish legislation in general, both of which have significantly stressed the rights of children. He argues that forcing members of the Lutheran Church to take part in Lutheran religious education at school curtails the rights both of the children and of their parents to express their opinion with respect to religious education at school. In his view, it is too drastic if, in order to exempt oneself from the Lutheran religious education at school, one needs to give up church membership. (Scheinin 2001, 515-7.) In contrast, however, the church historian, Juha Seppo, defending the principle of membership as the main criterion for having to attend religious education, argues that parents already have made their basic choice in joining a religious community, and it would only be confusing if they were forced to choose again (Seppo 2001, 520).

The obligation to attend Lutheran religious education on grounds of membership in the Lutheran Church is an example of a question pertaining to freedom of religion within a church or religious organisation, and within a state church in particular. As noted by Carolyn Evans, this line of thought sees churches as voluntary, private organizations - in similar fashion to different kinds of clubs - which give freedom to their members to remain within or leave a religion. She points out that this way of thinking fails to do justice to the complexities of the relationship between a believer and a church, and seems to give precedence to a religious organisation over the individual believers. (Evans 2001, 128, 132; Sakaranaho 2006, 338-9.) In so doing, it fails to recognize the diversity among members of a religious community, a diversity particularly characteristic of the Lutheran Church (see Niemelä 2003; Sakaranaho 2006, 33).

According to Scheinin $(2001,517)$, many Lutheran pupils, if given the chance, would actually choose Ethics rather than Lutheran religious education; and he suggests that it is the decreasing numbers of pupils in Lutheran religious education that is the ulterior motive for not allowing freedom of choice in this matter. However, in the present situation, where such freedom 
is not granted to Lutheran pupils, one can only speculate on its possible outcome (see Sakaranaho 2006, 338). ${ }^{30}$

In addition to issues about the religious education of the majority, one can also raise the question as to how far the particular model of Lutheran religious education, developed over several decades, can be directly applied to teaching minority religions. Treating religious minorities simply in the same fashion as the religious majority may be problematic, because of differences pertaining to their history and position in Finnish society as well as to their points of view with respect to religious education. (Sakaranaho \& Salmenkivi 2009, 465.) In Lutheran religious education, confessional religious education has already somewhat abated since the 1970s, when religious education in schools was dissociated from the preparation of pupils for their confirmation (see Seine 2000). In contrast to the Lutheran syllabus, the education of Orthodox and Catholic Christians has been closely connected to the catechetic education of these churches, encouraging pupils to an active commitment to the religious tradition in question. ${ }^{31}$ (See Pyysiäinen 2000, 77-80; see also Aikonen 1998; Aikonen 2007; Jaanu-Schröder 2007.) The same has been the case in religious education of Islam (see Sakaranaho 2006, 358-60).

In December 2003, the National Board of Education organized a seminar for the teachers of minority religions where, among other things, the nature of religious education was discussed. ${ }^{32}$ It was obvious that most of the Catholic and Orthodox teachers attending this seminar were not happy with the recent and proposed changes with regard to the confessional nature of religious education; they argued that teaching religion only in a 'demonstrative' sense was alien to Catholic and Orthodox tradition, where religion is seen as an integral part of everyday life and culture. The participants in this seminar also criticized the regulation that religious education should be devoid of religious practice (uskonnonharjoittaminen). It was admitted, nonetheless, that a term suitable for all religious traditions is hard to find.

\footnotetext{
30 According to a survey done in 2003 among school principals about the obligation of pupils to attend Lutheran religious education, they seem to be divided in this matter so that half of them favour freedom of choice between Lutheran religious education and Ethics education, and half are against it (Talli 2003). Unfortunately, there is no research available on the opinions of parents and pupils in this matter.

31 This is also in accordance with my personal observation of Catholic and Orthodox religious education in Helsinki and Espoo in autumn 2002, when I was attending their classes as a part of a course on teaching minority language and religions in school.

32 The following discussion is based on my personal observations in this seminar and was reported in Sakaranaho 2006.
} 
Hence, substituting 'religious practice' with terms such as 'cult' or 'rite' would be equally confusing and limited in their meaning. (See Sakaranaho 2006, 40-1.)

Moreover, the fact that religions can now be taught by a teacher who is not a member of the religious community in question has been criticized by teachers of minority religions. For instance, in teaching Orthodox religion it is felt that a non-Orthodox teacher does not necessarily have the required 'cultural reading skills' provided by personal experience of the Orthodox faith. From this point of view, education in accordance with one's own religion requires a teacher who is a member of the religious community whose religion is taught in class (Aikonen 2007, 52). Similar views have been expressed by teachers of Islam (Onniselkä 2011) and the Krishna movement (Paljakka 2008). Some Muslim parents have been unhappy with the way a non-Muslim teacher has taught Islam, and in some cases, they have transferred their children from Muslim education to Ethics education or to religious instruction provided by their Islamic community (see Onniselkä 2011, 127-8; see also Sakaranaho, forthcoming).

Despite these problems, fostering religious education in accordance with students' own religion and hence supporting plurality of religious education is seen by the Finnish state as a benevolent gesture of recognition towards religious minorities - and it is very much accepted as such among the teachers of these religions. At the same time, it is good to remember that the teachers of a minority religion represent only a small - and generally religiously active - minority within a minority, and therefore their views do not necessarily reflect the views of that religion's adherents in general (see Muhammed 2011). More research is therefore needed on these issues.

\section{Concluding Remarks}

In Finland, the pupils at the peruskoulu and lukio have the legal right - and even the obligation - to attend religious education 'in accordance with their religion', or Ethics education if they are not members of any registered religious community. Moreover, both religious education and Ethics education also involve pupils in learning about other religions and worldviews. The general aim, thereby, is to educate young people to be capable of taking part in cultural interaction as members of a rapidly globalizing world.

In sum, religious education in Finnish state-supported schools is 'separative' (Alberts 2007) and 'state-guaranteed', but not 'confessional' in the sense that religious communities might dictate the religious curriculum (cf. Jensen 
2002). The current system, however, is ridden with contradictions. While the institutionalized link between religious communities and the school has been more or less severed, students are still directed to religious education according to their membership in a religious community. On the other hand, teachers no longer need to be members of the religious community whose religion they teach. As discussed above, mismatch in religious affiliation between a teacher and the pupils and their parents has caused some confusion and dissatisfaction in minority religion education. Moreover, it is not really clear what exactly religious education 'in accordance with one's religion' implies. In Lutheran religious education, it involves 'learning about religion' and 'learning from religion' rather than 'learning religion', to use John Hull's (2001) terminology (see Kallioniemi 2007), whereas for the minority religions the emphasis is on fostering pupils' religious 'identity' (see Lyhykäinen 2009). Whatever the case may be, it is obvious that the needs of the religious majority and minorities are seen as different. What the current system does, then, is to reify the status quo of Lutheran religious education for the majority, while simultaneously extending the right to religious education to other religions. This 'system of extended privileges' is probably not unlike that in other European countries trying to come to terms with the growing multiculturalism of their societies (see Sakaranaho 2006, 117).

Looking at current religious education in Finland from a Study of Religions perspective, one can be happy with the growing emphasis on learning about different religions and worldviews. With the growing multiculturalism of Finnish society, the need for such education is on the increase rather than in decline. Consequently, the Study of Religions has an important role to play in the field of education. It can provide religious education with tools for 'learning about religion' and 'learning from religion', which is a mindset characteristic of the discipline. Moreover, the Study of Religions aims at educating members of society so that they can understand different religious traditions and worldviews. It can therefore act as an important educator for inter-cultural communication, an end towards which religious education in state-supported schools is working as well.

However, it is hard to say whether the Study of Religions as such should stand behind the current system of religious education, separating pupils by reference to their own religious affiliation into religious education or Ethics education; or whether it should rather promote an (integrative) approach to religious education that is the same for all pupils irrespective of their religious background. Perhaps the problem is not so much the system of religious education as it is run at the moment, but the way that pupils 
are directed into minority religion education or Ethics depending on their membership or not of a registered religious community. This kind of policy glosses over the huge internal diversity of beliefs and values characteristic of all religions - and, equally, of non-religious people as well. Integrated religious education, however, does not necessarily solve this problem. In practice, this diversity issue could be addressed within the current system of religious education, by granting the pupils at the peruskoulu and lukio, free choice between alternative options in religious education or Ethics education. Whatever the case may be, the Study of Religions can enhance people's awareness of diversity of beliefs and practices, irrespective of their membership or not of any religious community .

\section{Bibliography}

Act on the Integration of Immigrants and Reception of Asylum Seekers

1999 Act on the Integration of Immigrants and Reception of Asylum Seekers (493/1999, amendments up to 324/2009 included). Helsinki: Ministry of the Interior. <http://finlex.fi/en/laki/kaannokset/1999/en19990493. pd $>$, accessed 18 September 2013.

\section{Aikonen, Risto}

1998 Ortodoksinen uskonnonopetus Suomessa. - Markku Pyysiäinen \& Jarkko Seppälä (eds), Uskonnonopetuksen käsikirja, 405-439. Helsinki: WSOY.

2007 Koulun ortodoksinen uskonnonopetus: Haasteellisesta menneisyydestä uusiin oppimisympäristöihin. - Tuula Sakaranaho \& Annukka Jamisto, Monikulttuurisuus ja uudistuva uskonnonopetus, 42-73. Helsinki: Helsingin yliopiston uskontotieteen laitos.

\section{Alberts, Wanda}

2007 Integrative Religious Education in Europe. A Study-of-Religions Approach. Berlin: De Gruyter.

\section{Alitolppa-Niitamo, Anne}

2004 Somali Youth in the Context of Schooling in Metropolitan Helsinki: A Framework for Assessing Variability in Educational Performance. - Journal of Ethnic and Migration Studies 30 (1), 81-106.

Asetus opetustoimen henkilöstön kelpoisuusvaatimuksista

1998 Asetus opetustoimen henkilöstön kelpoisuusvaatimuksista 14.12.1998/986. <http://www.finlex.fi/fi/laki/ajantasa/1998/19980986>, accessed 12 September 2013. 
Basic Education Act

1998 Basic Education Act 628/1998. Amendments up to 1136/2010. <http:// www.finlex.fi/en/laki/kaannokset/1998/en19980628.pdf $>$, accessed 15 September 2013.

\section{Broo, Måns \& Janne Kontala}

2007 Krishna-uskonnon opetus Suomessa. - Tuula Sakaranaho \& Annukka Jamisto, Monikulttuurisuus ja uudistuva uskonnonopetus, 251-8.Helsinki: Helsingin yliopiston uskontotieteen laitos.

Constitution of Finland

1999 Constitution of Finland, 11 June 1999 (731 / 1999, amendments up to 1112 / 2011 included). Unofficial translation. Helsinki: Ministry of Justice. <http://www.finlex.fi/en/laki/kaannokset/1999/en19990731. pdf $>$, accessed 18 September 2013.

\section{Davie, Grace}

2000 Religion in Modern Europe. A Memory Mutates. Oxford: Oxford University Press.

Eduskunnan sivistysvaliokunnan lausunto

2002 Eduskunnan sivistysvaliokunnan lausunto 14 / 2012 vp. Hallituksen esitys uskonnonvapauslaiksi ja eräiksi siihen liittyviksi laeiksi. Helsinki: Eduskunta. <http://www.eduskunta.fi/triphome/bin/thw.cgi/trip/? $\$\{$ APPL $\}=$ utpvm\& $\$\{$ BASE $\}=$ faktautpvm\& $\$\{$ THWIDS $\}=0.3 / 13806271$ 83_282830\&\$\{TRIPPIFE $\}=P D F . p d f>$, accessed 1 October 2013.

\section{Evans, Carolyn}

2001 Freedom of Religion under the European Convention of Human Rights. New York: Oxford University Press.

Finnish Local Government

1981 Finnish Local Government. Helsinki: The Association of Finnish Cities and the Finnish Municipal Association.

\section{Heininen, Simo \& Markku Heikkilä}

2002 Kirchengeschichte Finnlands. Göttingen: Vandenhoeck \& Ruprecht.

\section{Hella, Elina \& Andrew Wright}

2009 Learning 'about' and 'from' religion: Phenomenography, the Variation Theory of Learning and Religious Education in Finland and the UK. - British Journal of Religious Education 31 (1), 53-64.

\section{Himanen, Timo}

2012 Cultural Diversity, Social Cohesion, Religion: Core Values and Educational policies in Four European Nations. Diss. Turun yliopisto: Annales Universitatis Turkuensis. 


\section{Holma, Markku}

2000 Finland. - Peter Schreiner (ed.), Religious Education in Europe. A Collection of Basic Information about RE in European Countries, 37-41. Münster: ICCS / Comenius-Institute.

\section{Hull, John M.}

2001 The Contribution of Religious Education to Religious Freedom: A Global Perspective. - Zarrin T. Caldwell (ed.), Religious Education in School: Ideas and Experiences from Around the World, 9-31. Boston: International Association for Religious Freedom.

\section{Iivonen, Pekka}

2004 Pienryhmäiset uskonnot ja niiden opettaminen. An unpublished paper. Helsinki: Opetushallitus.

2010 Uskonnonopetuksen tulevaisuus. An unpublished paper. Seminaari Arvon mekin ansaitsemme 5.-6.3. 2010. Helsinki: Suomen ekumeeninen neuvosto. <http://www.ekumenia.fi/sen_toimii/kasvatus_ja_ekumenia/arvot_mekin_ansaitsemme_5-632010/pekka_iivonen_uskonnonopetuksen_tulevaisuus/>, accessed 1 October $2 \overline{0} 13$.

\section{Jamisto, Annukka}

2007a Pienryhmäisten uskontojen opetus Suomessa ennen ja nyt. - Tuula Sakaranaho \& Annukka Jamisto, Monikulttuurisuus ja uudistuva uskonnonopetus, 31-41.Helsinki: Helsingin yliopiston uskontotieteen laitos.

2007b Opetussuunnitelmien valmisteluprosessi ja monikulttuurinen koulu. - Tuula Sakaranaho \& Annukka Jamisto, Monikulttuurisuus ja uudistuva uskonnonopetus, 117-125. Helsinki: Helsingin yliopiston uskontotieteen laitos.

\section{Jaanu-Schröder, Marjatta}

2007 Katolinen uskonnonopetus. - Tuula Sakaranaho \& Annukka Jamisto, Monikulttuurisuus ja uudistuva uskonnonopetus, 74-82. Helsinki: Helsingin yliopiston uskontotieteen laitos.

\section{Jensen, Tim}

2002 Religious education in public schools - A must for a secular state: A Danish perspective. - The CSSR Bulletin 31:4, 83-89.

\section{Kallioniemi, Arto}

2007 Näkökulmia eurooppalaiseen uskonnonopetukseen - oppiaineen kehittämisen haasteita Norjassa ja Suomessa. - Arto Kallioniemi ja Eero Salmenkivi (eds), Katsomusaineiden kehittämishaasteita. Opettajakoulutuksen tutkinnonuudistuksen virittämää keskustelua, 55-76. Tutkimuksia 279. Helsingin yliopisto: VOKKE ja Käyttäytymistieteellinen tiedekunta.

\section{Laki kansakoulun järjestysmuodon perusteista}

1923 Laki kansakoulun järjestysmuodon perusteista 137/1923. Suomen asetuskokolema vuodelta 1923. Helsinki: Valtioneuvsto (1924). 


\section{Leitzinger, Antero}

2006 Suomen tataarit. Vuosina 1868-1944 muodostuneen muslimiyhteisön menestystarina [The Tatars in Finland]. Helsinki: East West Books Helsinki.

\section{Laurence, Jonathan}

2012 The Emancipation of Europe's Muslims. The State's Role in Minority Integration. Princeton and Oxford: Princeton University Press.

\section{Liiten, Marjukka}

2003 Kuntaliitto esittää kouluun uskontotietoa. - Helsingin Sanomat, 16 Jan. 2003.

Lukiolain muutoksen vaikutus uskonnon ja elämänkatsomustiedon opetukseen sekä koulun toimintaan.

2006 Muistio: Lukiolain muutoksen vaikutus uskonnon ja elämänkatsomustiedon opetukseen sekä koulun toimintaan. Helsinki: Opetushallitus. <http://www.edu.fi/lukio/uskonto/lukiolaki.pdf>, accessed 20 August 2008.

\section{Lukiolaki}

$20039 \S$ (6.6.2003 / 455), Uskonnon ja elämänkatsomustiedon opetus. Finlex - Valtion säädöstietopankki.<http://www.finlex.fi/>, accessed 7 July 2013.

Lukion muiden uskontojen opetussuunnitelmien perusteet

2006 Lukion muiden uskontojen opetussuunnitelmien perusteet. Helsinki: Opetushallitus.

Lukion opetussuunnitelman perusteet

2003 Lukion opetussuunnitelman perusteet. Helsinki: Opetushallitus.

\section{Lyhykäinen, Kaarina}

2009 Praksis vai gnosis? Ortodoksisen uskonnon opettajien käsityksiä oppiaineen tehtävästä. -Teologinen Aikakauskirja. Teologisk Tidskrift 5, $471-7$.

\section{Maréchal, Brigitte}

2003 Modalities of Islamic Instruction. - Brigitte Maréchal, Stefano Allievi, Felice Dassetto, Jørgen Nielsen (eds), Muslims in the Enlarged Europe. Religion and Society, 19-77. Leiden, Boston: Brill.

\section{Muhammed, Husein}

2011 Kuka edustaa muslimeja? [Who represents the Muslims?] - Tuomas Martikainen \& Tuula Sakaranaho (toim.), Mitä muslimit tarkoittavat? Keskustelua islamilaisista virtauksista Suomessa ja Euroopassa [What the Muslims mean?], 115-21. Turku: Savukeidas. 
National Core Curriculum for Basic Education

2004 National core curriculum for basic education intended for pupils in compulsory education. Helsinki: Finnish National Board of Education. <http://www.oph.fi/english/sources_of_information/core_curricula_and_qualification_requirements/basic_education>, accessed 1 October 2013.

\section{Niemelä, Kati}

2003 Suomalaisten sitoutuminen uskonnollisiin yhdyskuntiin [Commitment of Finnish people to registered religious communities]. - Kimmo Kääriäinen, Kimmo Ketola, Kati Niemelä, Moderni kirkkokansa. Suomalainen uskonnollisuus uudella vuosituhannella [Modern churchgoers. Finnish religiosity in the new millenium], 122-47. Tampere: Kirkon tutkimuskeskus.

\section{Onniselkä, Suaad}

2011 Islamin opetus koulussa. Tuomas Martikainen and Tuula Sakaranaho (eds), Mitä muslimit tarkoittavat? Keskustelua islamilaisista virtauksista Suomessa ja Euroopassa [What the Muslims mean?], 122-38. Turku: Savukeidas.

\section{Paljakka, Tapio}

2008 Krishna-tietoisuuden uskonnon opetussuunnitelman analyysi vedisen koulutuksen ja kasvatuksen valossa. [An analysis of the Curriculum of Krishna consciousness religious education from the Vedic education's point of view]. Unpublished Master's thesis. Helsingin yliopisto: Soveltavan kasvatustieteen laitos.

\section{Perusopetuksen opetussuunnitelman perusteet}

2004 Oppivelvollisille tarkoitetun perusopetuksen opetussuunnitelman perusteet. Helsinki: Opetushallitus. <http://www.oph.fi/download/139848_ pops_web.pdf $>$, accessed 1 October 2013.

Perusopetuksen muiden uskontojen opetussuunnitelman perusteet

2006 Perusopetuksen muiden uskontojen opetussuunnitelman perusteet. Helsinki: Opetushallitus.

Perusopetuslain muutosten vaikutukset uskonnon ja elämänkatsomustiedon opetukseen sekä koulun toimintaan

2006 Muistio: Perusopetuslain muutoksen vaikutus uskonnon ja elämänkatsomustiedon opetukseen sekä koulun toimintaan [The Implications of the Changes in the Basic Education Act for the Education of Religion and Ethics as well as other practices of schools]. Helsinki: Opetushallitus. $<$ http://www.edu.fi/peruskoulu/uskonto/perusopetuslaki.pdf $>$, accessed 20 August 2008.

Perusopetuslaki

$200313 \S(6.6 .2003 / 454)$, Uskonnon ja elämänkatsomustiedon opetus. Finlex - Valtion sä̈̈döstietopankki. <http://www.finlex.fi/>, accessed 7 July 2013. 


\section{Pruuki, Lassi}

2009 Opettajan uskonnollisuuden merkitys koulukasvatuksessa ja uskonnon opetuksessa. - Teologinen Aikakauskirja. Teologisk Tidskrift 5, 387-403.

\section{Pyysiäinen, Markku}

2000 Yksi oppiaine, seitsemän opetussuunnitelmaa. Helsinki: Helsingin yliopiston soveltavan kasvatustieteen laitos.

\section{Saine, Harri}

2000 Uskonnonopetus Suomen oppivelvollisuuskoulussa 1900-luvulla. Turun yliopiston julkaisuja. Sarja C, osa 165. Turku: Turun yliopisto.

\section{Sakaranaho, Tuula}

2006 Religious freedom, Multiculturalism, Islam. Cross-reading Finland and Ireland. Leiden, New York: Brill.

2007 Pienryhmäisten uskontojen opetus ja monikulttuurisuuden haasteet. - Arto Kallioniemi \& Eero Salmenkivi (eds), Katsomuaineiden kehittämishaasteita. Opettajankoulutuksen tutkinnnonuudistuksen virittämää keskustelua, 3-16. University of Helsinki: Department of Teacher Education.

Forthcoming The Governance of Islamic education in Finland: Promoting 'General Islam' and the Unity of all Muslims. - Tuomas Martikainen, José Mapril \& Adil Hussain Khan (eds), Islam in the Margins of Europe. Leiden: Brill.

\section{Sakaranaho, Tuula \& Eero Salmenkivi}

2009 Tasavertaisen katsomusopetuksen haasteet: pienryhmäisten uskontojen ja elämänkatsomustiedon opetus Suomessa. - Teologinen Aikakauskirja. Teologisk Tidskrift 114 (5): 450-70.

\section{Salmenkivi, Eero}

2007 Elämänkatsomustieto ja sen opetus. - Tuula Sakaranaho \& Annukka Jamisto, Monikulttuurisuus ja uudistuva uskonnonopetus, 83-100. Helsinki: Helsingin yliopiston uskontotieteen laitos.

\section{Scheinin, Martin}

2001 Koulujen uskonnonopetus ihmisoikeuksien näkökulmasta. [Religious Education in Schools from a Human Right's Perspective.] - Teologinen Aikakauskirja. Teologisk Tidskrift 6, 515-7.

\section{Seine, Harri}

2000 Uskonnonopetus Suomen oppivelvollisuuskoulussa 1900-luvulla. Diss. Turku: Turun yliopisto.

\section{Seppo, Juha}

2003 Uskonnonvapaus 2000-luvun Suomessa. [Freedom of religion in the 21st Century Finland.] Helsinki: Edita. 


\section{Singleton, Fred}

1998 (1989) Short History of Finland. Cambridge: Cambridge University Press.

\section{Sisäasiainministeriö}

2008 Turvallinen elämä jokaiselle. Sisäisen turvallisuuden ohjelma. Valtioneuvosto: Sisäasianministeriö. <www.intermin.fi/download/25020_162008. pdf $>$, accessed 7 July 2013.

\section{Talli, Riikka}

2003 HS-selvitys: Islam tuli kouluihin. - Helsingin Sanomat, 22 Sept. 2003.

\section{Turner, Bryan S.}

2011 Religion and Modern Society. Citizenship, Secularisation and the State. Cambridge: Cambridge University Press.

Uskonnonvapauslaki

2003 Uskonnonvapauslaki 6.6.2003/453. - Finlex - Valtion säädöstietopankki. $<$ http://www.finlex.fi/>, accessed 7 July 2013.

Uskontotiede: Opinto-opas 2012-2013

2012 Helsinki: University of Helsinki. <http://www.helsinki.fi/teol/usktl/ OPINTO-OPAS_2012-13.pdf $>$, accessed 8 October 2013.

\section{Weintraub, Daniel}

2007 Juutalainen kasvatus ja uskonnonopetus. - Tuula Sakaranaho \& Annukka Jamisto (eds), Monikulttuurisuus ja uudistuva uskonnonopetus, 223-31. Helsinki: Helsingin yliopiston uskontotieteen laitos. 